\section{Military Technical College Kobry El-Kobbah, Cairo, Egypt}

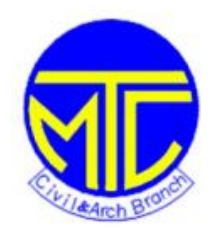

\title{
Numerical Modeling of Different Concrete Mixture Panels Resisting Projectile Penetration
}

\author{
Mostafa A. Hazem ${ }^{1}$, Essam M. El-Tehewy ${ }^{1}$ and Ismail M. Kamal ${ }^{1}$
}

\begin{abstract}
Penetration depth induced by projectiles through concrete target is an essential design parameter for fortification structures. Due to the expensive costs of field test experiments, numerical modeling is considered one of the most efficient procedures to predict the response of concrete mixture panels under the effect of impact loads.

In the present paper, finite element model (FEM) is proposed to model response of different concrete mixture panels subjected to the impact load. 3-D nonlinear finite element analysis (FEA) is used. Seven concrete mixtures are prepared and tested in the present study to obtain the suitable concrete mixture panels. These concrete mixtures can improve the performance of the concrete panels to resist projectile penetration. S ilica fume and fly ash are used as additives to concrete mixtures. Based on plain concrete panel, the experimental projectile results published in another study are used to verify the results obtained by the proposed 3-D FEM. The finite element program AUTODYNE-3D is used to model the concrete panels .

The mechanical properties of different concrete mixtures are tested and obtained from experimental work. There is a good agreement between the results obtaine $\mathrm{d}$ by both the 3-D FEA and the published experimental test. The responses of the proposed concrete panels are expressed as displacement time history and analyzed and presented. The proposed concrete mixtures improve the performance of the concrete panels against projectile penetration.
\end{abstract}

Keywords: Reinforced concrete; Penetration, silica fume, Fly ash, Finite element analysis

\section{1- Introduction}

Understanding the response of concrete due to penetration is essential in order to assign the safety of fortified structures under dynamic load induced by conventional weapons attacks. The finite element program is capable of analyzing very complex material constitutive equations [1]. The present study introduces different concrete mixtures. The concrete panels are made of plain concrete with and without admixtures. Silica fume (SF) and Fly Ash (FA) are used as additives to plain concrete in the present study.

Variation of admixture ratio in concrete mixtures res ults a variation in the mechanical properties of concrete, which may affect the penetration resistance of the concrete panels. This paper employs the explicit dynamic finite element code 3D- AUTODYN to analyze the behavior of reinforced concrete panels during projectile penetration. The RHT concrete model is a modular strength model for brittle materials developed by Reidel, Hiermaier and Thoma of Ernst Mach Institute [2], Model shows relatively good agreement with experimental results. It can also be used for other brittle materials such as rock and ceramic [3]. 


\section{2- Experimental Programs:}

The experimental work was carried out to study the different mechanical properties of different type of concrete mixture panels. The additives affect the mechanical properties of the concrete mixtures.

In the present study, seven concrete mixtures are prepared and tested as discussed below. The difference between the seven mixtures lies on the use of the additives.

The first mixture (NC) is only made of plain concrete. The NC mixture has $350-\mathrm{kg} / \mathrm{m}^{3}$ cement, $1400-\mathrm{kg} / \mathrm{m}^{3}$ Dolomite, $700-\mathrm{kg} / \mathrm{m}^{3}$ sand, and $175-\mathrm{kg} / \mathrm{m} 3$ water.

The second mixture (NC1) is only made of plain concrete. The $\mathrm{NC} 1$ mixture has $650-\mathrm{kg} / \mathrm{m}^{3}$ cement, $900-\mathrm{kg} / \mathrm{m}^{3}$ Dolomite, $450-\mathrm{kg} / \mathrm{m}^{3}$ sand, and $270-\mathrm{kg} / \mathrm{m} 3$ water.

The third mixture (NC2) is only made of plain concrete. The NC2 mixture has $400-\mathrm{kg} / \mathrm{m}^{3}$ cement, $1200-\mathrm{kg} / \mathrm{m}^{3}$ Dolomite, $600-\mathrm{kg} / \mathrm{m}^{3}$ sand, and $160-\mathrm{kg} / \mathrm{m} 3$ water.

The fourth mixture (NC3) is made of plain concrete with the SF an d the FA. The NC3 mixture has $320-\mathrm{kg} / \mathrm{m}^{3}$ cement, $1200-\mathrm{kg} / \mathrm{m}^{3}$ Dolomite, $600-\mathrm{kg} / \mathrm{m}^{3}$ sand, $160-\mathrm{kg} / \mathrm{m} 3$ water, $40-\mathrm{kg} / \mathrm{m}^{3} \mathrm{SF}$, and $40-\mathrm{kg} / \mathrm{m}^{3} \mathrm{FA}$.

The fifth specimen is (N.C4) contains $\left(280 \mathrm{~kg} / \mathrm{m}^{3}\right)$ cement, $\left(1200 \mathrm{~kg} / \mathrm{m}^{3}\right)$ Dolomite, $\left(600 \mathrm{~kg} / \mathrm{m}^{3}\right)$ sand, (160kg $/ \mathrm{m} 3)$ water, $(40 \mathrm{~kg} / \mathrm{m} 3)$ S.F, $(80 \mathrm{~kg} / \mathrm{m} 3)$ P.F.A and $(6 \mathrm{~kg} / \mathrm{m} 3)$ S.P. The sixth specimen is (N.C5) contains $\left(240 \mathrm{~kg} / \mathrm{m}^{3}\right)$ cement, $\left(1200 \mathrm{~kg} / \mathrm{m}^{3}\right)$ Dolomite, $\left(600 \mathrm{~kg} / \mathrm{m}^{3}\right)$ sand, $(160 \mathrm{~kg} / \mathrm{m} 3)$ water, $(40 \mathrm{~kg} / \mathrm{m} 3)$ S.F, $(120 \mathrm{~kg} / \mathrm{m} 3)$ P.F.A and $(6 \mathrm{~kg} / \mathrm{m} 3)$ S.P. The seventh specimen is (N.C6) contains $\left(200 \mathrm{~kg} / \mathrm{m}^{3}\right)$ cement, $\left(1200 \mathrm{~kg} / \mathrm{m}^{3}\right)$ Dolomite, $\left(600 \mathrm{~kg} / \mathrm{m}^{3}\right)$ sand, $(160 \mathrm{~kg} / \mathrm{m} 3)$ water, $(40 \mathrm{~kg} / \mathrm{m} 3)$ S.F, (160 kg/m3) P.F.A and $(6 \mathrm{~kg} / \mathrm{m} 3)$ S.P. Specimens were cast for each mixture to assess compressive strength and drying density after 3, 7, 28, 90 days, all specimens, upon their removal from molds, were stored under standard water curing tank until required for testing.

The concrete modulus of elasticity determined from equation (1) [5].

$$
\mathrm{E}=\mathrm{k}_{1} \cdot \mathrm{k}_{2} \cdot 3 \cdot 35 \cdot 10^{4} \cdot(\gamma / 2 \cdot 4)^{2} \cdot\left(\sigma_{\mathrm{B}} / 60\right)^{1 / 3}
$$

$\mathrm{k}_{1} \ldots \ldots . .$. correction factor with regard to coarse aggregates ranges from 0.95 to 1.2

$\mathrm{k}_{2} \ldots \ldots \ldots$ correction factor with regard to mineral additions ranges from 0.95 to 1.0

Table (1) present the compression strength and calculated young's modulus for the tested concrete mixtures.

Table (1) Compression strength and young's modulus for normal weight concrete

\begin{tabular}{|c|c|c|c|c|c|c|}
\hline \multirow{2}{*}{ Specimen } & \multicolumn{4}{|c|}{ Compressive strength $\left(\mathrm{kg} / \mathrm{cm}^{2}\right)$} & \multicolumn{3}{c|}{ Mechanical properties } \\
\cline { 2 - 7 } & $\begin{array}{c}3 \\
\text { days }\end{array}$ & $\begin{array}{c}7 \\
\text { days }\end{array}$ & $\begin{array}{c}28 \\
\text { days }\end{array}$ & $\begin{array}{c}90 \\
\text { day }\end{array}$ & $\begin{array}{c}(\mathrm{\gamma}) \\
\text { Density } \\
\left(\mathrm{g} / \mathrm{cm}^{3}\right)\end{array}$ & $\begin{array}{c}\text { (E) } \\
\text { Young's modulus } \\
(\text { Mpa })\end{array}$ \\
\hline N.C & 212 & 277 & 307 & 350 & 2.36 & 32478.79 \\
\hline N.C1 & 238 & 293 & 329 & 395 & 2.45 & 36443.29 \\
\hline N.C2 & 228 & 286 & 316 & 385 & 2.55 & 39142.97 \\
\hline N.C3 & 333 & 400 & 527 & 617 & 2.55 & 45806.65 \\
\hline N.C4 & 166 & 295 & 415 & 512 & 2.5 & 43045.07 \\
\hline N.C5 & 125 & 272 & 390 & 493 & 2.55 & 42505.9 \\
\hline
\end{tabular}




\begin{tabular}{l|l|l|l|l|l|l} 
N.C6 & 117 & 141 & 300 & 422 & 2.55 & 40358.75
\end{tabular}

\section{1- Concrete panel model verification}

The verified selected problem was a field-penetration test carried out by Moh.A.El-Sayed. [1]. the field layout is shown in Fig (1), three targets were considered in this verificati on (SC2, SC3 AND SE 8-1), (SC2, SC3) made from plain concrete panels, while (SE 8-1) were made from ferrocement concrete panel, all panels prepared from mix (N.C) with dimensions $550 \times 550$ x $200 \mathrm{~mm}$ and located as shown in Fig (2). The description of the targets are shown in table (2). Expanded steel meshes were employed to reinforce the ferrocement concrete panels, data and properties of steel mesh used are given in table (4). The projectile used was blunt-nose steel penetrator $23 \mathrm{~mm}$ diameter and $64 \mathrm{~mm}$ length as shown in Fig (3), the material properties of the penetrator shown in table (3). The impact velocity was $980 \mathrm{~m} / \mathrm{sec}$.

Fig (1) Penetration resistance test Rig on the SC2.

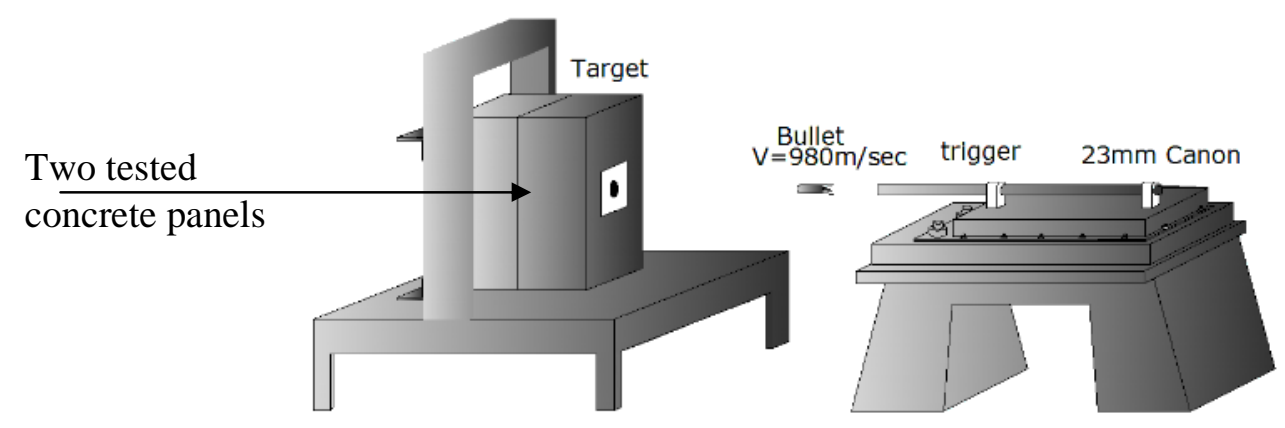

Table (2): Specimens detail

\begin{tabular}{|c|c|c|c|c|c|c|}
\hline \multirow{2}{*}{ NO } & \multirow{2}{*}{ Name } & Specimens description & $\begin{array}{c}\text { Thick. } \\
(\mathrm{cm})\end{array}$ & front & rear & \multicolumn{2}{|c|}{$\begin{array}{c}\text { No.of } \\
\text { panels }\end{array}$} \\
\hline 1 & SC 2 & $(2 \times 20 \mathrm{~cm})$ plain concrete & 40 & - & - & $\square$ \\
\hline 2 & SC 3 & $(3 \times 20 \mathrm{~cm})$ plain concrete & 60 & - & - & $\square$ \\
\hline 3 & SE 8-1 & $\begin{array}{c}(2 \times 20 \mathrm{~cm}) \text { ferrocement panel each } \\
\text { with 2 mesh (style 1038) }\end{array}$ & 40 & 1 & 1 & $\square$ \\
\hline
\end{tabular}



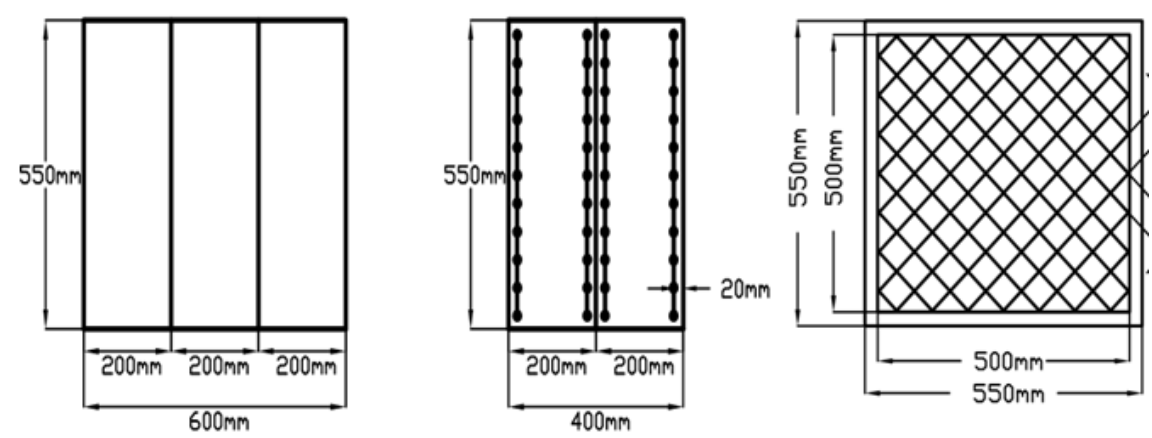

Figure(2) Dimensions and details of the specimen
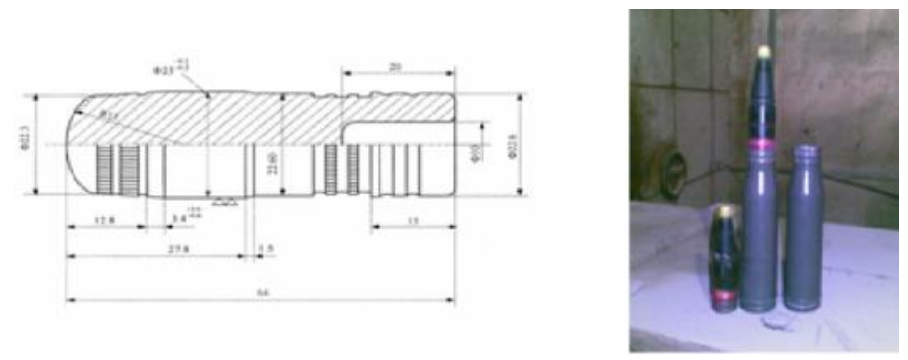

Fig (3): Dimension of $23 \mathrm{~mm}$ API missile

Table (3) Mechanical properties of the 23 AP projectile materials

\begin{tabular}{|c|c|c|c|}
\hline $\begin{array}{c}\text { Brinell hardness } \\
(\mathrm{HB})\end{array}$ & $\begin{array}{c}\text { Yield strength } \\
{[\mathrm{MPa}]}\end{array}$ & $\begin{array}{c}\text { Ultimate strength, } \\
{[\mathrm{MPa}]}\end{array}$ & $\begin{array}{c}\text { Strain to } \\
\text { fracture, }[\%]\end{array}$ \\
\hline 475 & 1726 & 1900 & 7 \\
\hline
\end{tabular}

Table (4): Data of expanded steel mesh used

\begin{tabular}{|c|c|c|c|c|c|c|c|}
\hline & \multicolumn{7}{|c|}{ Dim. Expanded metal style 1038} \\
\hline & $\begin{array}{l}\text { Sheet } \\
\text { size }\end{array}$ & $\begin{array}{l}\text { Sheet } \\
\text { weight } \\
(\mathrm{kg})\end{array}$ & $\begin{array}{c}\text { Thickness } \\
\text { (mm) }\end{array}$ & $\begin{array}{l}\text { LWO } \\
(\mathrm{mm})\end{array}$ & $\begin{array}{l}\text { LWD } \\
(\mathrm{mm})\end{array}$ & $\begin{array}{l}\text { SWO } \\
(\mathrm{mm})\end{array}$ & $\begin{array}{l}\text { SWD } \\
(\mathrm{mm})\end{array}$ \\
\hline & $100 x 800$ & $14 \mathrm{~kg}$ & 1 & 30 & 38 & 12 & 14.5 \\
\hline $\begin{array}{c}\text { Mechanical } \\
\text { properties of Expanded } \\
\text { metal style } 1038\end{array}$ & $\begin{array}{l}\text { Density } \\
(\mathrm{kg} / \mathrm{m} 3)\end{array}$ & \multicolumn{2}{|c|}{$\begin{array}{l}\text { Yield Strength } \\
(\mathrm{MPa})\end{array}$} & \multicolumn{2}{|c|}{$\begin{array}{c}\text { Ultimate } \\
\text { Strength }(\mathrm{MPa})\end{array}$} & \multicolumn{2}{|c|}{$\begin{array}{c}\text { Modulus of } \\
\text { Elasticity }(\mathrm{GPa})\end{array}$} \\
\hline Value & 7850 & \multicolumn{2}{|r|}{250} & \multicolumn{2}{|r|}{460} & \multicolumn{2}{|c|}{210} \\
\hline
\end{tabular}




\section{Numerical Model Method}

Three dimensional finite element model was used to simulate the penetration and perforation of reinforced concrete target.

\subsection{Mesh generation}

Lagrange processor has been used in AUTODYN for the analyses, in this paper two classes of target panels were considered. Unreinforced (plain) concrete and reinforced concrete (ferrocement), projectile and the concrete target are modeled as Lagrangi an meshes in all models, while the reinforcing steel bars (meshes) were described as multiple two directional beam elements in ferrocement models, all parts were symmetry on $\mathrm{X}=0$ planes to reduce the size of the computational domain.

\subsubsection{Projectile Mesh}

The geometry of the projectile part, as shown in Fig (4), was defined using a structured Lagrangian mesh, and was divided to 21 nodes in the I-direction, 11 nodes in the J-direction and 21 nodes in the K-direction. The IJK-index corresponds to the Cartesian co-ordinate system.
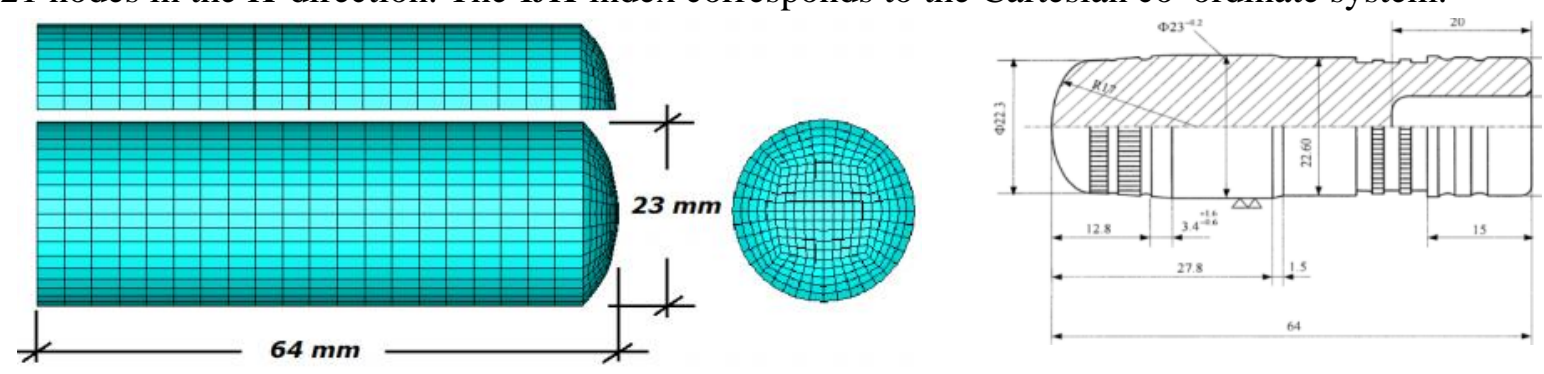

Fig (4) Geometry and Meshing of the Projectile Part

\subsubsection{Plain Concrete Mesh}

For model SC2 and SC3, target 1\&2 of plain concrete material (Conc.35MPa) were defined using a structured Lagrangian mesh, every panel was divided to 29 nodes in the $I$-direction, 56 nodes in the $J$-direction and 21 nodes in the $K$-direction, Zoning technique was used to dense the meshes in critical region. Fig (5) shows the geometry and meshing of model SC 2 \& SC3.
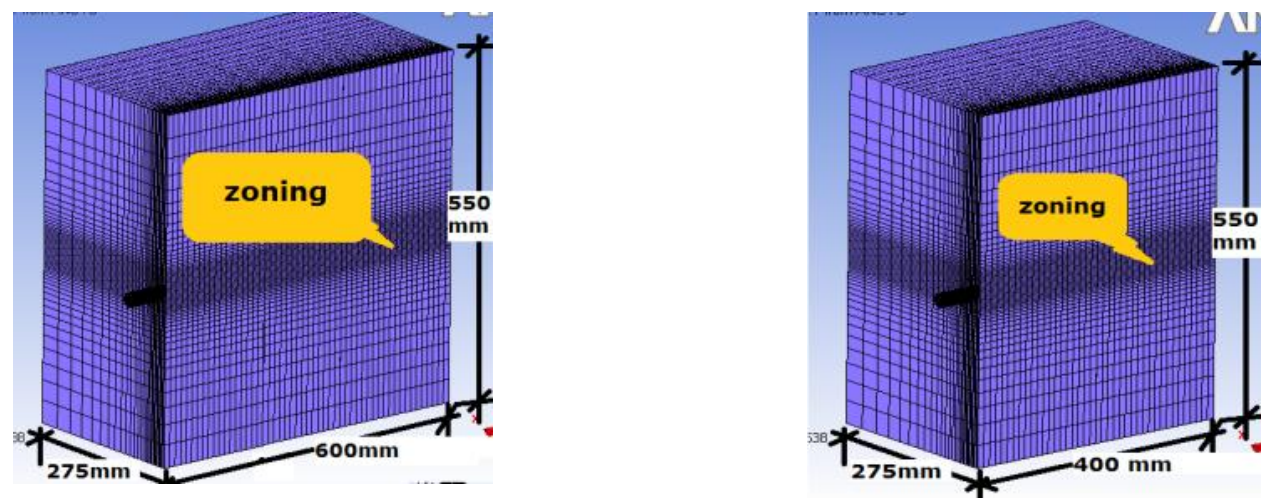

Fig (5) Geometry and meshing for plain concrete

\subsubsection{Ferrocement Mesh}

The ferrocement model SE8-1 contains target $1 \& 2$ of concrete material (Conc.35MPa) and steel mesh layers of (STEEL 4340) beside projectile part.

Target 1\&2 were defined as SC2 and SC3, Steel layer were defined using 3011 two directional beam element for each layer. Fig (6) shows the geometry and meshing of model S E8-1. 


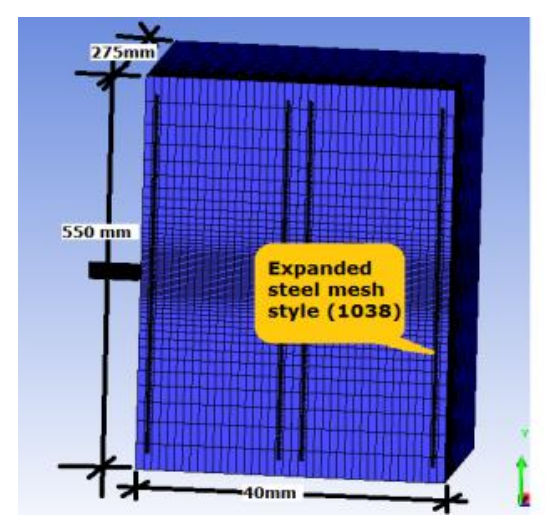

Fig (6) Geometry and meshing for Ferrocement Mesh

\subsection{Material Modeling}

The governing equations are the conservation of mass, momentum and energy. To complete the description of the continuum, additional relations desc ribing the material behavior is the material model which typically four basic types of information must be specified for each material [3]:

1. Equation of State: Pressure as function of density and internal energy .

2. Strength model: Strength model, which defines the yield surface.

3. Failure model: Failure model prescribing when the material no longer has strength

4. Erosion model: Erosion criteria. When a material is eroded it is transformed from solid element to a free mass node (Lagrange only).

RHT strength model, by Riedel, [6, 7] was used for modeling the dynamic loading of concrete, because the model computes the following phenomena assoc iated with brittle materials: Pressure hardening, Strain hardening, Strain rate hardening, Volumetric compaction (using the P -alpha Equation of State) [8].

The main material parameter for concrete was chosen from the AUTODYN material library (Concrete $35 \mathrm{MPa}$ ) and modified according to the values investigated experimentally as reported in Table (1), the material model used to represent steel mesh material was Johnson Cook strength model [8], the main material parameter for steel was chosen from the AUTODYN material library (STEEL 1006) and modified according to the values ob tained from material data sheet, the main material parameter for ste el used in projectile was chosen from the AUTODYN material library (STEEL 4340) and modified according to the values ob tained from material data sheet, The Erosion model used was geometric strain.

\subsection{Model Interaction and Boundary Conditions: -}

Projectile-concrete interaction was achieved using the gap interaction logic. In the gap interaction logic, each surface segment is surrounded by a contact detection zone. The radius of this contact detection zone is called the gap size. Any node entering the contact detection zone of a surface segment are repelled by a force proportional to the depth of penetration of the node into the contact detection zone [3].

The initial condition for projectile part in all model were $980 \mathrm{~m} / \mathrm{sec}$ in $\mathrm{Z}$ direction and the boundary conditions in all model for all target parts were constant veloc ity in $Y$ direction $V_{y}=0$ and for target were constant velocity in $\mathrm{Z}$ direction $\mathrm{V}_{\mathrm{Z}}=0$.

\section{Validation of Numerical Model}

To validate the experimental results numerically, three dimensional finite element models were 
performed see table (5) for the set of experimental tests [4], using the same method presented above. The response of the concrete panels was determined in terms of penetration depth and front and rear damaged areas. These parameters are used to identify the penetration resistance of concrete panels.

Table (5) the finite element model for the set of experimental tests

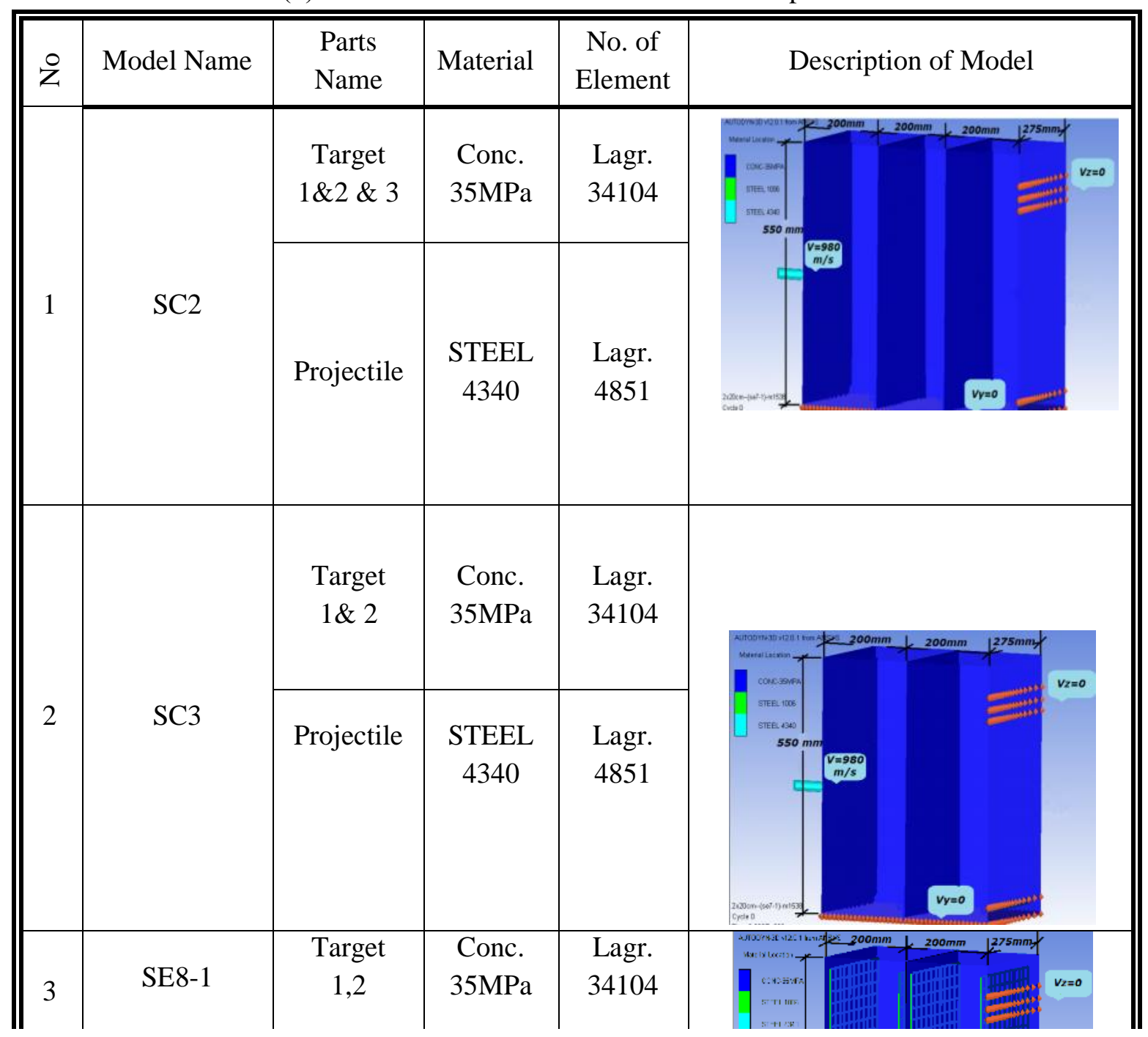




\begin{tabular}{||l|c|c|c|l||}
\hline & Steel & STEEL & Beam & \\
& Mesh 1-4 & 1006 & 3011 & \\
& & & & \\
\cline { 2 - 4 } & Projectile & STEEL & Lagr. & \\
& & 4340 & 4851 & \\
& & & & \\
\hline
\end{tabular}

\section{Validation Results}

A comparison between finite element models results and experimental results is presented in table (6), according to penetration depth, damage in front and rear face.

Table (6) finite element models results and experimental results

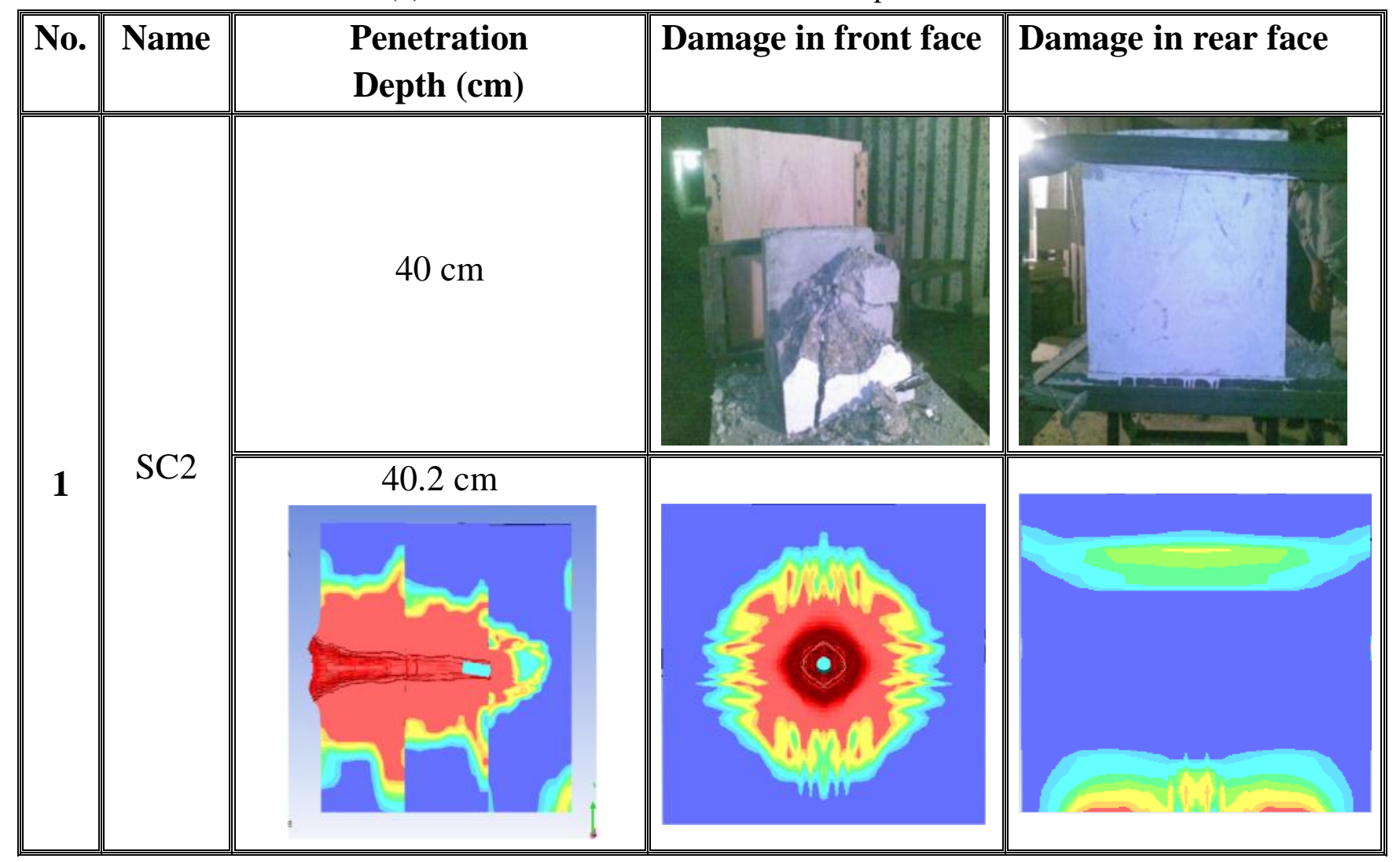




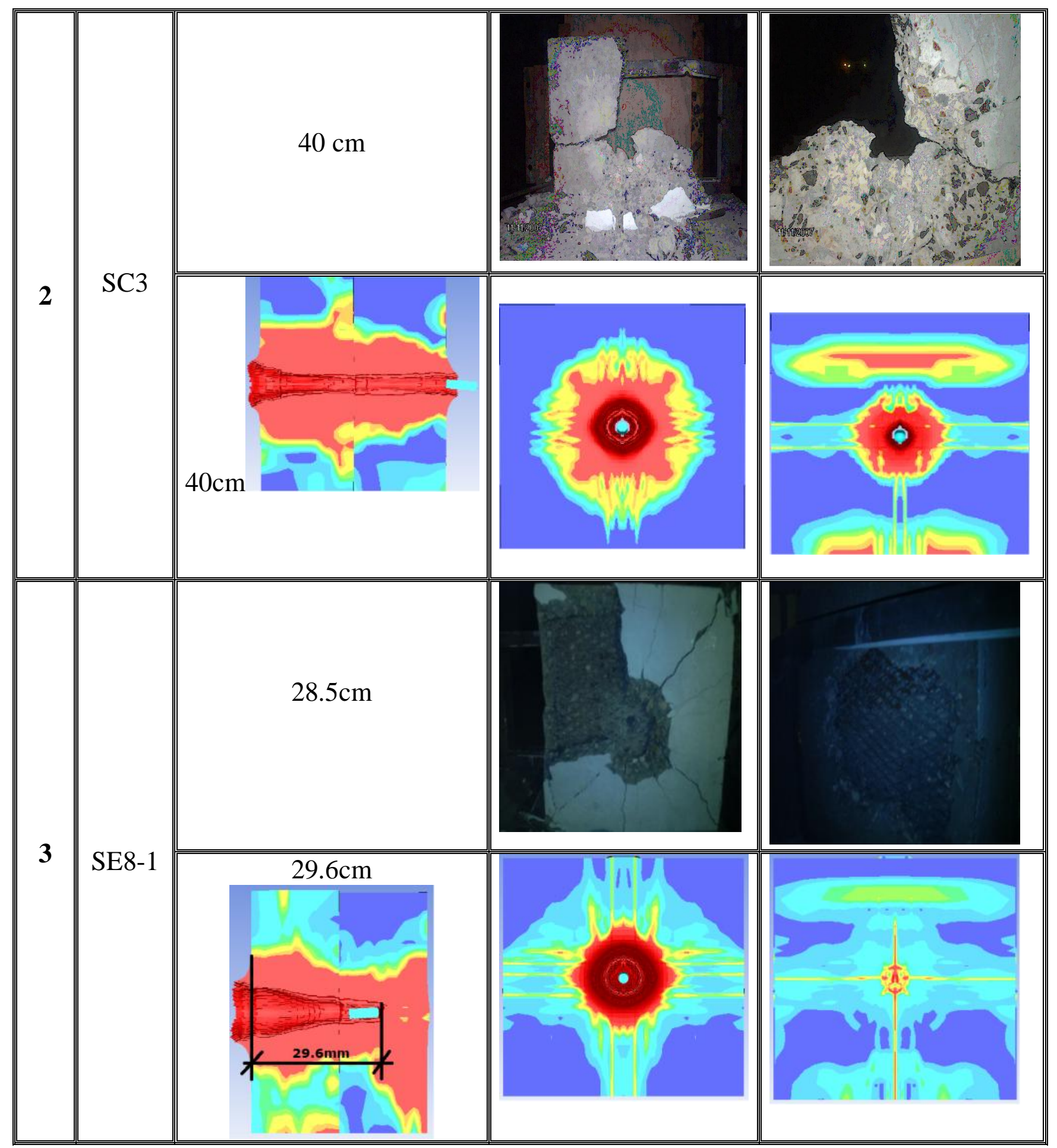

\section{Effect of Concrete mixture on Penetration Resistance}

N.C3 shows best penetration resistance as shown in table (7) and front /rear damage, using 10\% silica fume \& $10 \%$ Fly ash replacement with cement by weight .

Table (7) finite element models results for normal weight concrete. 
Proceedings of the $\mathbf{9}^{\text {th }}$ ICCAE-9 Conference, 29-31 May, 2012

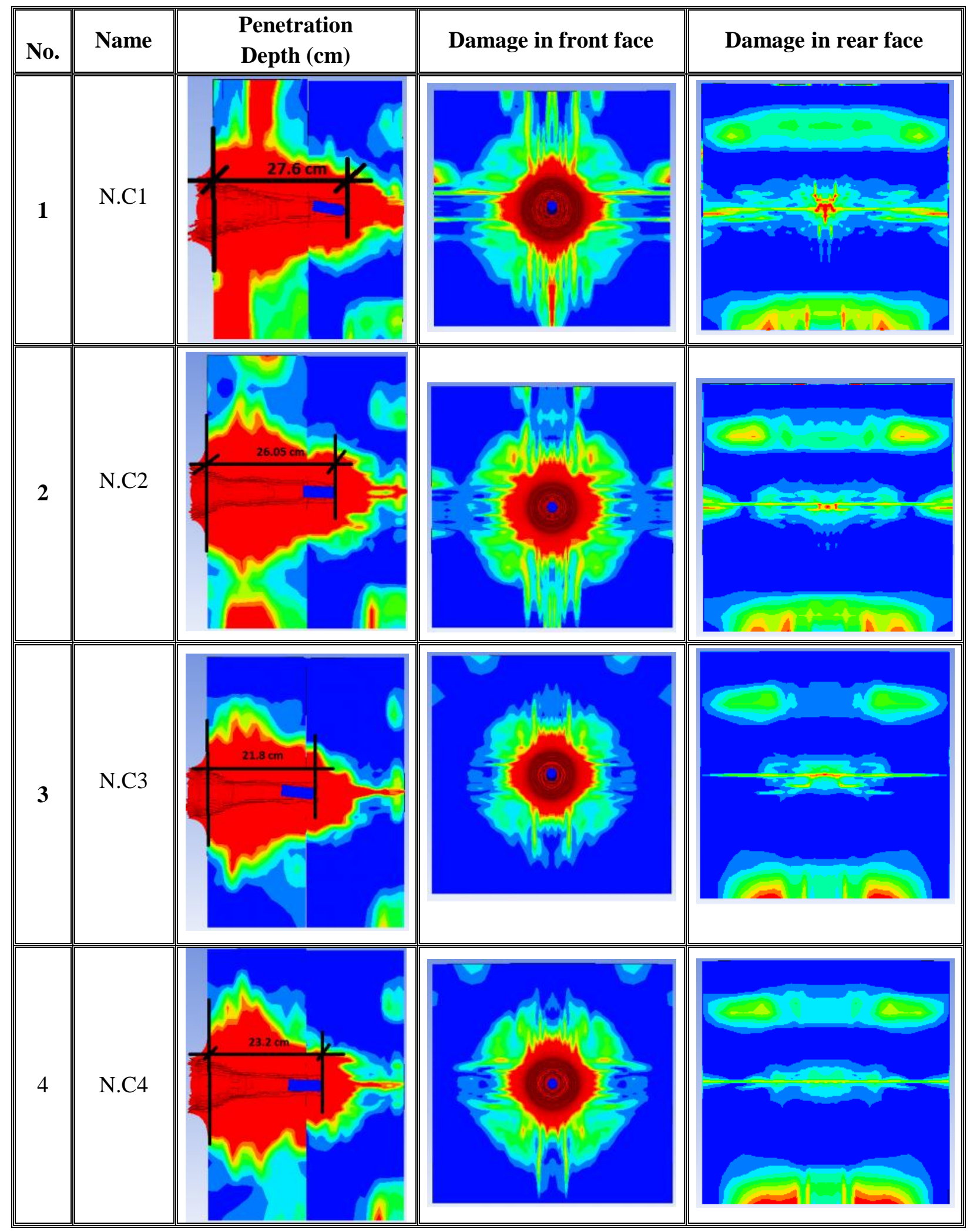




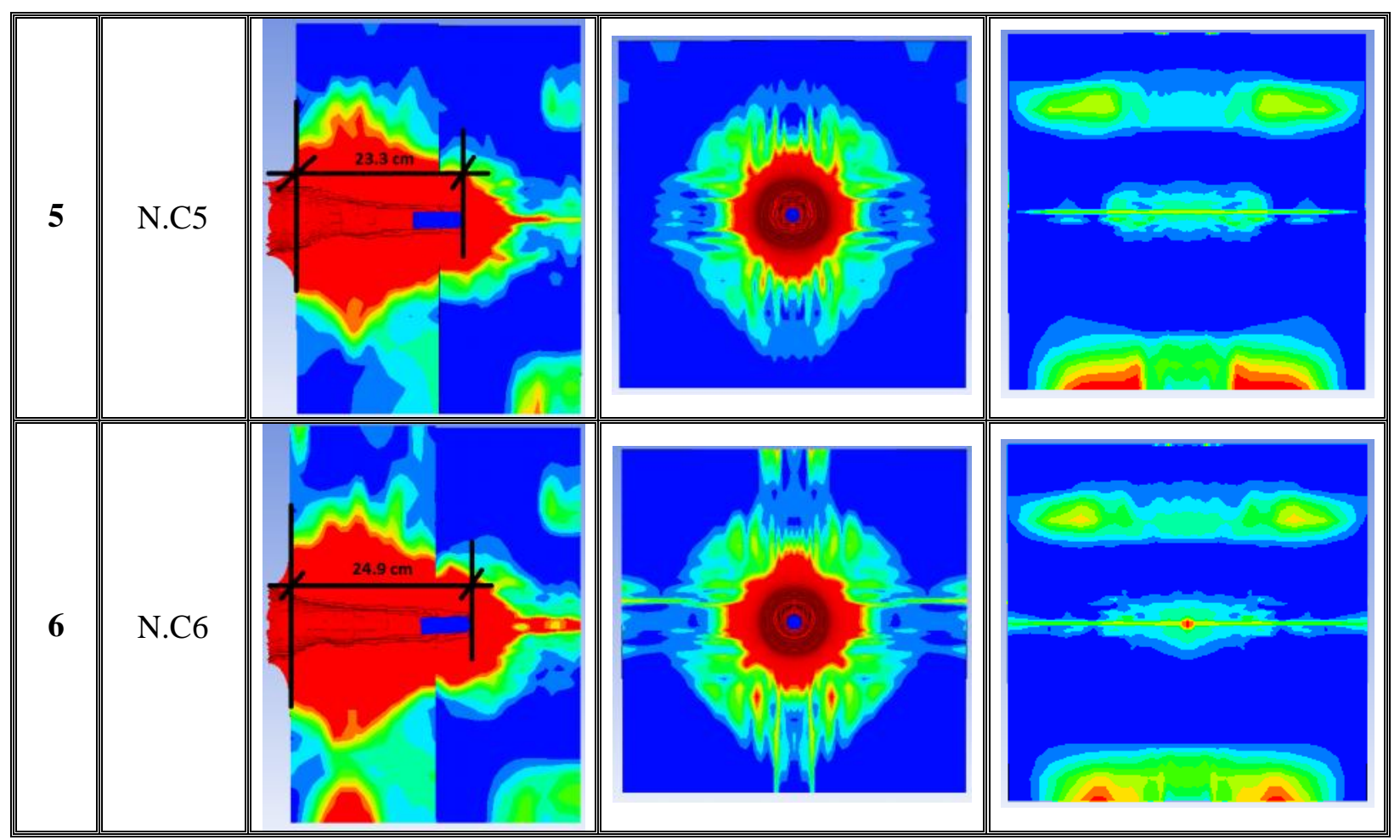

\section{Conclusions}

The proposed finite element model can be used efficiently in characterizing the behavior of concrete panels under the effect of projectile penetration. The reliability of this model performance is demonstrated by a comparison between finite element models results and experimental ones. It exhibited qualitatively correct behavior compared with the experimental investigation results.

Also, concrete mixtures with $10 \%$ S.F and $10 \%$ PFA reduce the penetration depth of concrete panels by $26 \%$, with remarkable reduction in both front and rear face damage .

\section{References}

[1] J. Leppanen, "Dynamic Behaviour of concrete Structur es subjected to Blast and Fragment Impacts," 2002.

[2] S. o. E. a. E. Institute for Infrastructure and Environment, University of Edinburgh, Edinburgh EH9 3JL, UK, "Evaluation of typical concrete material models used in hydrocodes for high dynamic response simulations," International Journal of Impact Engineering, 2009.

[3] A. AUTODYN, "Mechanical (formerly Simulation)," TUTORIAL, November 2009.

[4] Moh.Ali, "Missile Effect on Different Types of Concrete," 2010.

[5] F. T. a. T. Noguchi, "Relation ship betwe en Compressive Strength and Modulus of Elasticity of High-Strength Concrete," Dept. of Architecture, Fac. of Engineering, Univ. of Tokyo.

[6] P. S. Hakan Hansson, "Simulation of Concrete Penetration in 2D and 3D with the RHT Material Model," SWEDISH DEFENCE RESEARCH AGENCY, 2002.

[7] C. Y. Tham, "Reinforced concrete perforation and penetration simulation usingAUTODYN-3D," Computational Mechanics Division, Institute of High Performance Computing, 1 Science Park Road, \#01-01 The Capricorn,Singapore Science Park II, Singapore 117528, 2005. 
[8] M. E. Mohamed, "Design a Special Concrete Mixture to Resist Penetration of Hyper Velocity Objects," 2009. 